\title{
Research on the Impact of China's OFDI and Domestic Inter- regional Industrial Transfer on Industrial Upgrading
}

\author{
Lu-Qing ZHANG \\ School of Management, Capital Normal University, \\ P.R. China, 100089 \\ E-mail: zhangluqing9966@163.com
}

\begin{abstract}
Countries around the world are all very concerned with effective upgrading of their own industrial structure. Both outward foreign direct investment (OFDI) and domestic inter-regional transfer of industry are effective measures of optimizing industrial structure and increase industrial competitiveness. At present, China's OFDI is developing fast. Domestic inter-regional transfer of industry has grown in scale meanwhile. This paper has done the research on effect of these two measures to adjustment of industrial structure and their interrelation. At last, this paper gives suggestion on how to promote the adjustment of China's industrial structure through these two measures.
\end{abstract}

Keywords-Outward foreign direct investment (OFDI), Domestic inter-regional transfer of industry, Industrial upgrading

\section{INTRODUCTION}

With the development of economic globalization, the worldwide economy has been more and more closely related. The joint movement of worldwide industries is very common. It has made the distribution of international industry more and more optimized. During this process, we should consider the distribution of international industry and Chinese current conditions in order to promote Chinese economy and industrial upgrading. We should synthetically use two measures of international transfer and domestic inter-regional transfer of industry in order to avoid industrial hollowing-out resulted from outward foreign direct investment (OFDI). We should also consider the actual undertaking ability of domestic undertaking regions. The industrial transfer cannot be done just only for transfer.

\section{The LATEST DEVELOPMENT OF CHINESE OFDI AND ITS IMPACT ON INDUSTRIAL UPGRADING}

Chinese OFDI has been developing very fast since 2002. According to Statistical Bulletin of China's Foreign Direct Investment, the flow of Chinese OFDI in 2015 is 145.67 billion U.S. dollars which grows for successive 13 years. By the end of 2015, the stock of Chinese OFDI is 1097.86 U.S. dollars. The flow and stock of Chinese OFDI account for $9.9 \%$ and $4.4 \%$ of those of world respectively. The flow of Chinese OFDI ranks 2nd in 2015 among worldwide countries and the stock of Chinese OFDI ranks 8th in 2015 from 25th in 2002. The amount of merger and acquisition (M\&A) in 2015 is 56.9 billion U.S. dollars which accounts for $46.2 \%$ of flow and becomes the main entry mode. By the end of 2015, Chinese 20.2 thousand domestic investors have established 30.8 thousand foreign direct investment enterprises which locate in 188 countries (regions). In 2015 , nearly $80 \%$ of non-finance foreign direct investment is from local enterprises which are main part of foreign direct investment. The flow of local non-finance foreign direct investment is 93.6 billion U.S. dollars which rises $71 \%$ year on year and accounts for $77 \%$ of nationwide non-finance foreign direct investment. The east part, middle part and west part of China rise by $78.2 \%, 84.7 \%$ and $14.2 \%$ respectively. The flow of Shanghai, Beijing and Guangdong break 10 billion U.S. dollars and are the first three among local investment in 2015.

According to the classification in [1], the motives of OFDI are divided into resource-oriented, efficiency-oriented, market-oriented and technology-oriented. While in [3], OFDI is divided into 'gradient OFDI' and 'adverse gradient OFDI' according to flow direction of OFDI. 'Gradient OFDI' means that investment flows from relatively developed country to relative less developed country. The investing enterprises can make use of existing technology and ability and get better production condition and big short-run profit through transferring domestic relatively disadvantageous industry. The motive of this kind of investment is resource-oriented and efficiency-oriented. 'Adverse gradient OFDI' means that investment flows to relatively developed country from relatively less developed country. The investing enterprises aim to procure visible and invisible assets from developed country which promote the development in the future. The motive of this kind of investment is more inclined to market-orientation and technology-orientation.

OFDI with different motives has different impact on home country's industrial upgrading. The following is the impact mechanism of OFDI with different motives to industry upgrading in home country as figure 1 shown. 
Figure 1. Impact of OFDI with different motives to industrial structure in home country

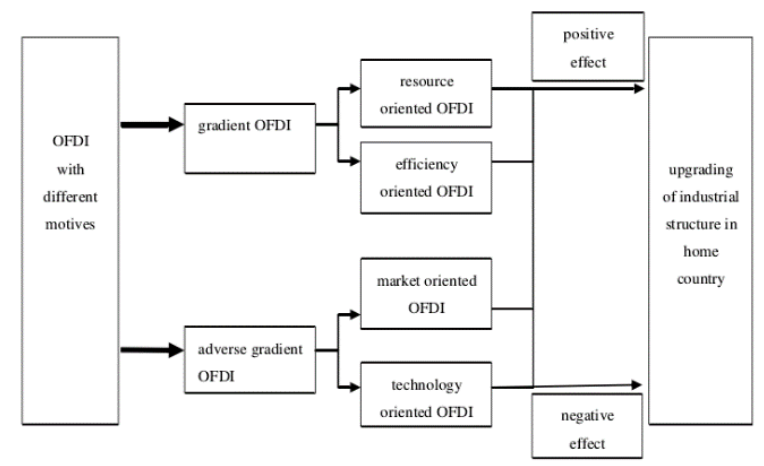

There are differences among the impacts of OFDI with different motives to industry upgrading in home country.

\section{A. Resource-oriented OFDI}

It refers to OFDI which aims to get rich productive resource from host country because there lacks resource in home country. The positive effect is the increase of resource supply and export. It can alleviate resource restriction of industrial development and promote export of intermediate goods so as to improve industrial upgrading in home country. The negative effect is low end locking effect. Resource-oriented OFDI can strengthen the advantage of traditional industry which may result in insufficient impetus of industrial upgrading and solidification of position of division of labor.

\section{B. Efficiency-oriented OFDI}

It refers to OFDI which flows to host country with rich labor resource because of rise of wage in home country. It aims to save cost and increase efficiency. The positive effect is optimization of position of division of labor. Efficiency-oriented OFDI can transfer labor intensive process out and guide resource into value-added part so as to realize industrial upgrading. The negative effect is employment substitute effect. Efficiency-oriented OFDI can result in reduction of labor demand and surplus unskilled labor force. It brings structural unemployment in short run because surplus unskilled labor force cannot meet the requirement of high end industry. It delays process of industrial upgrading.

\section{Market-oriented OFDI}

It refers to OFDI which aims to enlarge market share in host country because of market saturation in home country. The positive effect is to avoid trade barrier and transfer excess capacity. Market-oriented OFDI can effectively avoid high cost resulted from tariff and non-tariff barriers in host country and transfer domestic undigested production capacity out. It promotes industrial upgrading through strengthening effective market demand outside home country. The negative effect is export substitute effect. It is easy for market-oriented OFDI to substitute the export of home country. It may reduce industrial investment scale and do harm to industrial upgrading especially when crowding out effect is big enough.

\section{Technology-oriented OFDI}

It refers to OFDI which aims to get the technology and brand in host country because technology upgrading in home country is blocked. The positive effect is reverse technology spillover and profit return. Technology-oriented OFDI uses overseas advanced technology in domestic industrial development through transnational merger and acquisition (M\&A) and jointly research and development (R\&D). It can also put overseas profit into domestic R\&D. These measures can increase productivity and realize industrial upgrading. The negative effect is path dependent effect. Technology-oriented OFDI easily makes industrial development seriously dependent on the technology in host country. The motive of independent innovation is insufficient. This excess dependence on technologic introduction easily makes domestic industry lose first mover advantage.

As far as positive effect of OFDI to home country's industrial structure is concerned, it brings upgrading of home country's industrial structure which reflects the rise of home country's comparative advantage. But we must pay attention to the negative effect of OFDI to home country's industrial structure. It may bring industrial hollowing in home country.

\section{THE LATEST DEVELOPMENT OF CHINESE INTER-REGIONAL INDUSTRIAL TRANSFER AND ITS IMPACT ON INDUSTRIAL UPGRADING}

Industrial transfer means that some industries relocate from one country (region) to another country (region) according to the difference of resource and factor endowment. It is one kind of worldwide and regional economic movement. It is the enterprise relocation in micro perspective which means enterprise transfers part or full of production from original place to the other place. Enterprise relocation involves reselection of enterprise's address, comparison of cost and income, and etc. The main motive of enterprise relocation is minimization of cost and maximization of profit. Minimization of cost mainly depends on cost of factor. From macro perspective, enterprise relocation means that in case of market economy some enterprises in developed districts relocated to other less developed districts because of all kinds of reasons especially the change of comparative advantage. There is a phenomenon that industry moves from developed region to less developed region. So industrial transfer is defined as the move of industry and enterprise as the carrier of industry in geographic space.

Since reform and opening up, China began to attract foreign investment and undertake international industrial transfer in order to improve Chinese economic development and industrial structure. At the beginning, China mainly undertook labor intensive industries among which processing trade has largest proportion. Later on, China 
gradually undertook capital intensive and technology intensive industries. There were more and more undertaking modes. China enters the large scale and diversified phase of undertaking international industrial transfer after 2001. There comes 'two way industrial transfers' in this phase. On the one hand, China actively undertakes technology intensive and capital intensive industries from developed countries. On the other hand, China begins to transfer relatively matured labor intensive industry to middle and west part of China and other countries with comparative advantage.

At present, Chinese inland has entered new phase of optimizing layout of industrial chain, transition of industrial transfer and economic development. Firstly, the industries transferred from eastern coastal region to inland region are not restricted in traditional low end manufacturing industries. Some high end industries with high technology and added value such as electronic information, high end equipment manufacturing and new energy begin to transfer to inland region. Secondly, some advantageous industries such as petrochemical industry, nonferrous metals industry and etc. begin to transfer to eastern costal region. $R \& D$ and market departments in these industries are usually transferred to eastern coastal region so that rich human resource, rich commercial information and wide market in eastern costal region can be fully used. This adverse transfer of industries didn't appear in former phase. Industrial structure undertaken by inland region is gradually optimized.

\section{INTERACTION BETWEen CHINESE OfDi AND \\ DOMESTIC INTER-REGIONAL INDUSTRIAL TRANSFER}

The flying-geese theory put forward by [2] can explain industrial transfer to some extent. The flying-geese industrial transfer directly comes from dynamic change of comparative advantage. With the rise of per capita income, factor endowment in one country will change so as to relocate resource in different industries. For example, the main industry in one country is from labor intensive industry to capital intensive and technology intensive industry. But the change path of comparative advantage and flying-geese model has different characteristics in big economy and small economy. From economic perspective, the structure of resource endowment and industrial structure are homogeneous in small economy. The whole small economy enters new phase once there is changes in comparative advantage. There are differences among different regions in big economy. Some regions enter new phase while some regions are still in old stage. So flying-geese model for small country usually refers to industrial transfer and undertaking among independent economy. The flying-geese model for big country usually refers to industrial transfer and undertaking among domestic different regions.

China is the biggest developing country in the world so that Chinese OFDI and industrial development has its own characteristics. There is obvious gradient in economic development of domestic regions. Economic development decreases in turn from eastern part to middle part to western part so that gradient industrial transfer is possible in China. Gradient industrial transfer in domestic regions is another way to transfer industry besides OFDI. It not only transfers industries with comparative disadvantage out so as to provide space for industries with comparative advantage, but also effectively avoids industry hollowing.

\section{V.CONCLUSION}

During gradient industrial transfer from eastern developed region, especially efficient oriented investment, we should give priorities to middle and western less developed regions in China. During adverse gradient industrial transfer from eastern developed region, especially strategic asset oriented investment; we should give priorities to foreign developed countries.

During adverse gradient industrial transfer from middle and western less developed region of China, whether market oriented investment or strategic asset oriented investment, we should give priorities to eastern developed regions in China. For middle and western less developed regions in China, even if the condition is not allowed, we should consider gradient OFDI in advance according to the program of industrial structure.

\section{REFERENCES}

[1]. J. H. Dunning. Location and the Multinational Enterprise: A Neglected Factor \& Quest. Journal of International Business Studies, 2009 (40): 5 19.

[2]. Kojima, Kiyoshi. The 'Flying Geese' Model of Asian Economic Development: Origin, Theoretical Extensions, and Regional Policy Implications. Journal of Asian Economics, 2000(11): 375 401.

[3]. Sui Yue Hong. Dual Outward Foreign Direct Investment and Trade Structure: Theory and Evidence from China. International Business, 2010(6):66 73. (in Chinese) 